\title{
Airborne gamma-ray spectrometric domains in Guaratubinha Basin, southern Brazil: a tool for geologic mapping
}

Leonardo Mairink Barão1, Francisco José Ferreira Fonseca², Luís Gustavo de Castro², Barbara Trzaskos². ${ }^{1}$ Programa de Pós-Graduação em Geologia da Universidade Federal do Paraná. ${ }^{2}$ Departamento de Geologia da Universidade Federal do Paraná

Copyright 2016, SBGf - Sociedade Brasileira de Geofísica

Este texto foi preparado para a apresentação no VII Simpósio Brasileiro de Geofísica, Ouro Preto, 25 a 27 de outubro de 2016. Seu conteúdo foi revisado pelo Comitê Técnico do VII SimBGf, mas não necessariamente representa a opinião da SBGf ou de seus associados. É proibida a reprodução total ou parcial deste material para propósitos comerciais sem prévia autorização da SBG.

\section{Abstract}

The association of gamma-ray spectrometry with fieldworks it proved effective as a geologic mapping on areas with difficult access, like occur on Guaratubinha Basin. The gamma spectrometric response of basic radionuclides $\mathrm{K}$, eTh and $\mathrm{eU}$, provides a delineation of five radiometric domains, which related can be to a three distinct geologic units of the basin: Miringuava, Vossoroca e Serra do Salto formations. The volcanic and volcanoclastic infill of the Basin, affords a different response of gamma spectrometric data, thereby facilitating the characterization of geologic units presents on the basin.

\section{Introduction}

The Guaratubinha Basin is one of the transitional basins of southern Brazil (Almeida, 1969). It is located about 30 $\mathrm{km}$ of Curitiba city, State of Paraná (Fig. 1). This basin was first described during the 60's, initially named as a Guaratubinha Formation (Fuck et al., 1967). This basin was formed on high-grade metamorphic rocks of the Luiz Alves Terrain at the end of Neoproterozoic, dated on $604 \pm 8.6 \mathrm{Ma}$ (Siga Jr. et al., 2000). It is infill consists by immature sedimentary rocks, acid to intermediate volcanic rocks and volcanoclastic rocks (Castro et al., 1993). The volcanic rocks of the basin has an excellent response for airborne gamma-ray spectrometric data. The ratios of the radionuclides (eU/eTh, eU/K and $\mathrm{eTh} / \mathrm{K}$ ) highlight different radiometric domains. The separation of these domains contributed directly to definition of geologic units. The correlation of field works and the gamma-ray spectrometry it is show to be effective in the following working. This approach makes possible direct correlations between the radiometric signature of the basin rocks and the corresponding geologic units. It was possible recognized three stratigraphic units: Miringuava Formation (conglomerates sandstones and argillites), Vossoroca Formation (andesites) and Serra do Salto Formation divided on three members (Osso da Anta Member, Serra dos Castelhanos and Escutador Member), constituted by rhyolites and volcanoclastic rocks (Fig. 4).

\section{Methods}

The airborne radiometric data were acquired by Geological Survey of Brazil in 2011 (CPRM, 2011), along north-south flight lines spaced at $500 \mathrm{~m}$, with a mean terrain clearance of $100 \mathrm{~m}$. The tie lines had $10 \mathrm{~km}$ spacing. From these data were generated the basic ( $\mathrm{K}$, eTh, eU) and ternary maps (Fig. 2), a three variables combination like described by several authors (e.g. Anderson \& Nash, 1997; Wilford et al., 1997; Minty, 1997; Gunn et al. 1997; IAEA, 2003). After the creation of these maps, we separated five gamma spectrometric domains based on relative concentrations of the radionuclides in each domain (Fig. 3). These maps were correlated with data collected in the field works, like a rocks lithotype and structural information, to generate a geologic map on scale of 1:50,000. Finally, we compared the geologic map with the radiometric domains, proving the use of this tool to geologic mapping (Fig. 4).

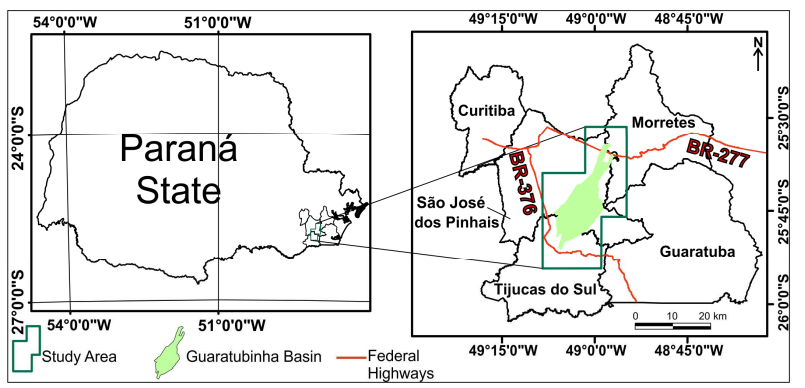

Figure 1 - Location of the study area.

\section{Results}

The five radiometric domains were obtained by the correlation between the $\mathrm{K}$, eTh, eU and ternary maps (Figs. 3 and 4), which are described below:

A Domain: characterized by the rocks of Vossoroca Fm. covering large extension on north and southern region, marked by the predominance of $\mathrm{K}$ compared to others radionuclides (Figs. $2 \mathrm{a}$ and $3 \mathrm{a}$ ). This response is related with the presence of amygdales filled by clay minerals.

B Domain: marked by high response of eU and average levels of eTh and $\mathrm{K}$, different from the adjacent areas (Figs. 2 and 3).

C Domain: formed by rhyolitic rocks of Escutador Member, the domain has high concentration of $\mathrm{K}$ and $\mathrm{eTh}$ (Figs. 2 and 3), compatibles to mineralogical composition of these rocks. The average levels of eU are possibly associated with the sloping relief (Figs. 2 and 3).

D Domain: involved by southeast segment of domain A (Figs. 2 and 3 ) the $D$ domain is marked by high concentration of $\mathrm{K}$, eTh and eU. This response is the reflex of mineralogical composition of volcanoclastic rocks like lapilli-tuffs, tuffs and ignimbrites. This region has high 
grade of weathering, in the form of clayey regolith, which retains radionuclides.

E Domain: it has the smallest area of the radiometric domains, formed mainly volcanoclastic rocks. Marked by average concentrations of $\mathrm{K}$ and $\mathrm{eU}$, but high levels of eTh, this domain is possibly linked to clay minerals derived from surface modification of volcanoclastic rocks.

\section{Discussion and Conclusions}

The recognition of the gamma-ray spectrometric domains associated with the fieldwork it is an essential tool for geologic mapping, especially in areas with difficult access, dense vegetation and areas with steep slopes, as is the case of the Guaratubinha Basin. The radiometric domains (Fig. 3) shows the correlation of the radionuclides in each domain, based on the variation of concentration of the $\mathrm{K}$, eTh and eU. Comparing the radiometric domains to geologic map (Figure 4), we visualize the correlation of the mapped units with domains, justifying the use of the method to geologic cartography.

\section{Acknowledgments}

The authors thanks to Companhia de Pesquisa de Recursos Minerais (CPRM, Geological Survey of Brazil) for permission to use the radiometric data. This research was supported by CNPQ under contract number 481065/2013-0 (Tectônica e Sedimentação da Bacia Guaratubinha Project). L.M. Barão is grateful to Coordination for the Improvement of Higher Education Personnel (CAPES) for scholarship. F.J.F. Ferreira was supported in this research by a felowship from National Council for Scientific and Technological Development (CNPq) (contract 306978/2015-6).

\section{References}

Almeida, F. F. M. de, 1969. Diferenciação tectônica da Plataforma Brasileira (Tectonic differentiation of the Brazilian Platform). Proceedings 33rd. Brazilian Geological Congress, Salvador (BA), Brazil, vol. 1: 29-46.

Anderson, H., Nash, C., 1997. Integrated Lithostructural Mapping of the Rossing Area, Namibia Using High Resolution Aeromagnetic, Radiometric, Landsat Data and Aerial Photographs. Exploration Geophysics, 28, 185191.

Castro et al (02 co-authors), 1993. Rochas Vulcanogênicas da Formação Guaratubinha, PR. In: Anais do V Simp. Sul Bras. de Geol., Curitiba, 43-44.

CPRM, 2011. Projeto Aerogeofísico Paraná-Santa Catarina (PR, SC, SP). Companhia de Pesquisa de Recursos Minerais (CPRM), Serviço Geológico do Brasil. Comunicado sobre a disponibilização de dados digitais aerogeofísicos (Magnetometria e Gamaespectrometria), $1-14 p$.
Fuck et al (02 co-authors), 1967. A Formação Guaratubinha. Boletim Paranaense de Geociências, vol. 23, 237-256.

IAEA, 2003. Guidelines for radio element mapping using gamma ray spectrometry data. $179 p$.

Minty, B. R. S., 1997. Fundamentals of airborne gammaray spectrometry. AGSO Journal of Australian Geology \& Geophysics, 17(2), 39-50.

Gunn, P. J. et al (02 co-authors), 1997. The Airborne Gamma-Ray Spectrometric Response Over Arid Australian Terranes. In: GUBINS AG (Eds.). Proceedings of Exploration 97: Fourth Decennial International Conference on Mineral Exploration. Australia, p. 733-740.

Siga Jr. et al (04 co-authors), 2000. U-Pb and Sm-Nd Isotopic Studies of Campo Alegre and Guaratubinha Volcanosedimentary Basins, Southern Region. In: Anais do Cong. Bras. Rio de Janeiro, 31.

Wilford, J. R.et al (02 co-authors), 1997. Application of airborne gamma-ray spectrometry in soli/regolith mapping and applied geomorphology. AGSO Journal of Australian \& Geophysics, 17(2), 201-216. 


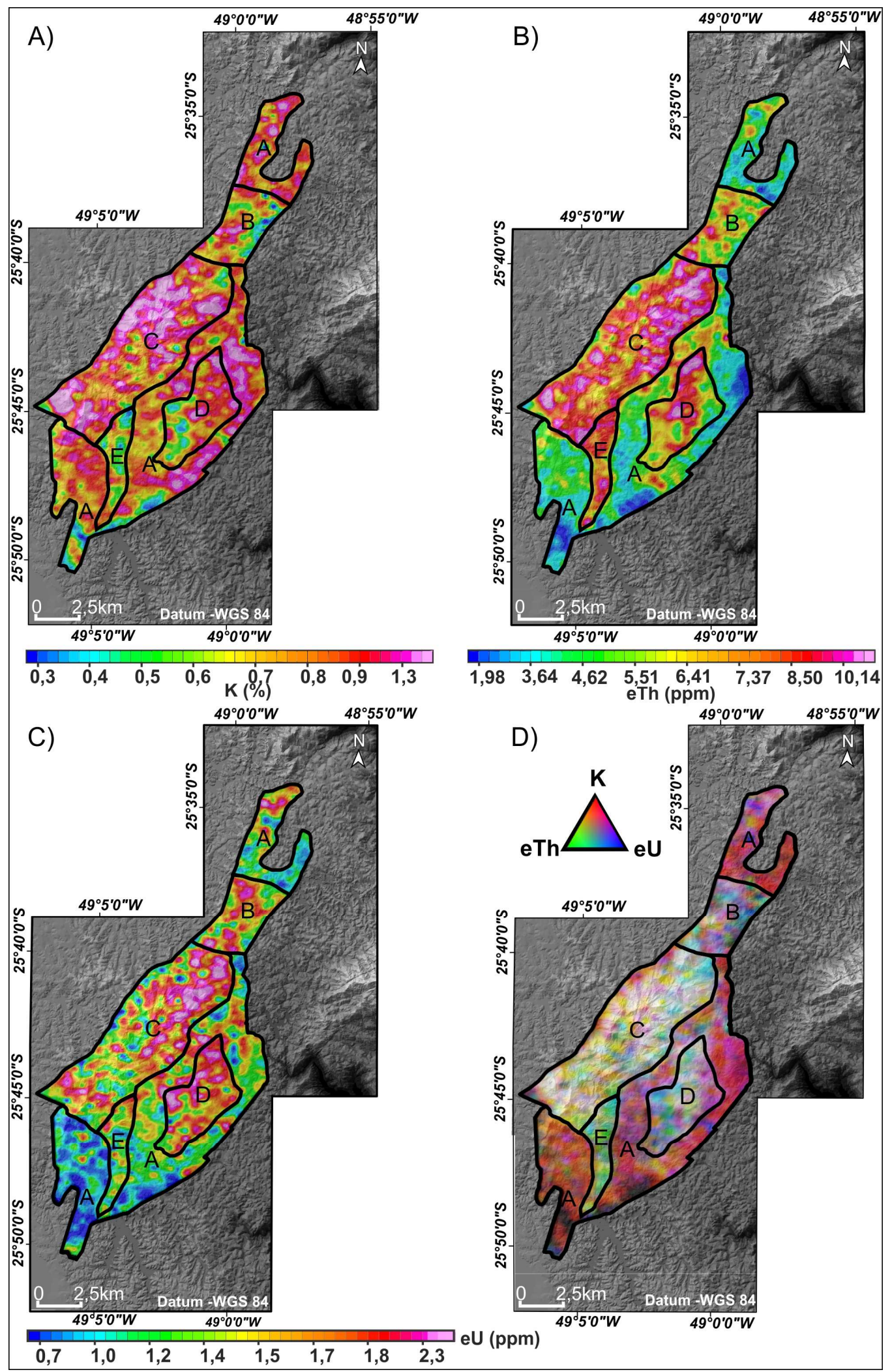

Figure 2 - Radiometric maps of the study area. A) K (\%), B) eTh (ppm), C) eU (ppm), D) ternary. 


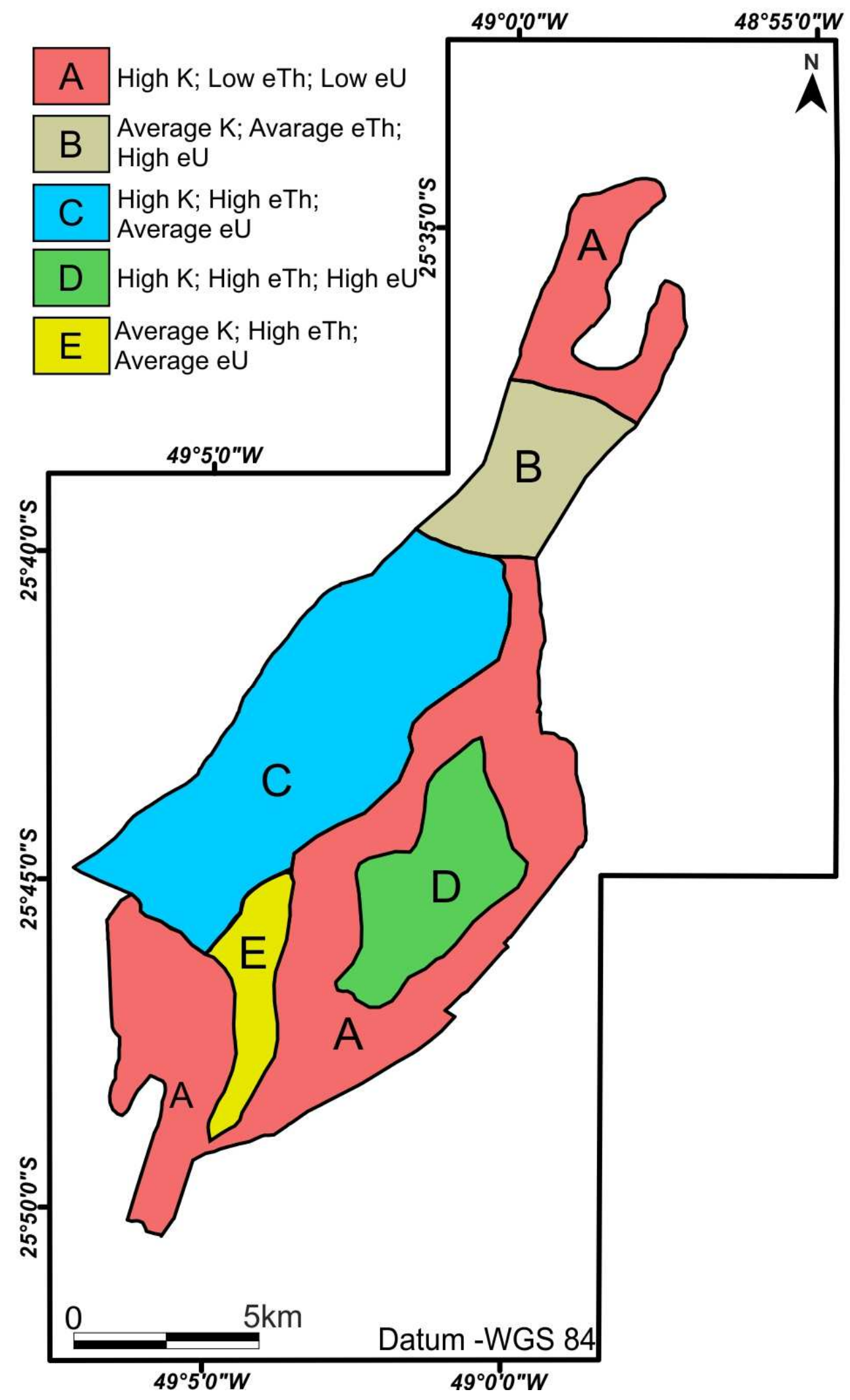

Figure 3 - Gamma-ray spectrometric domains of the study area. 


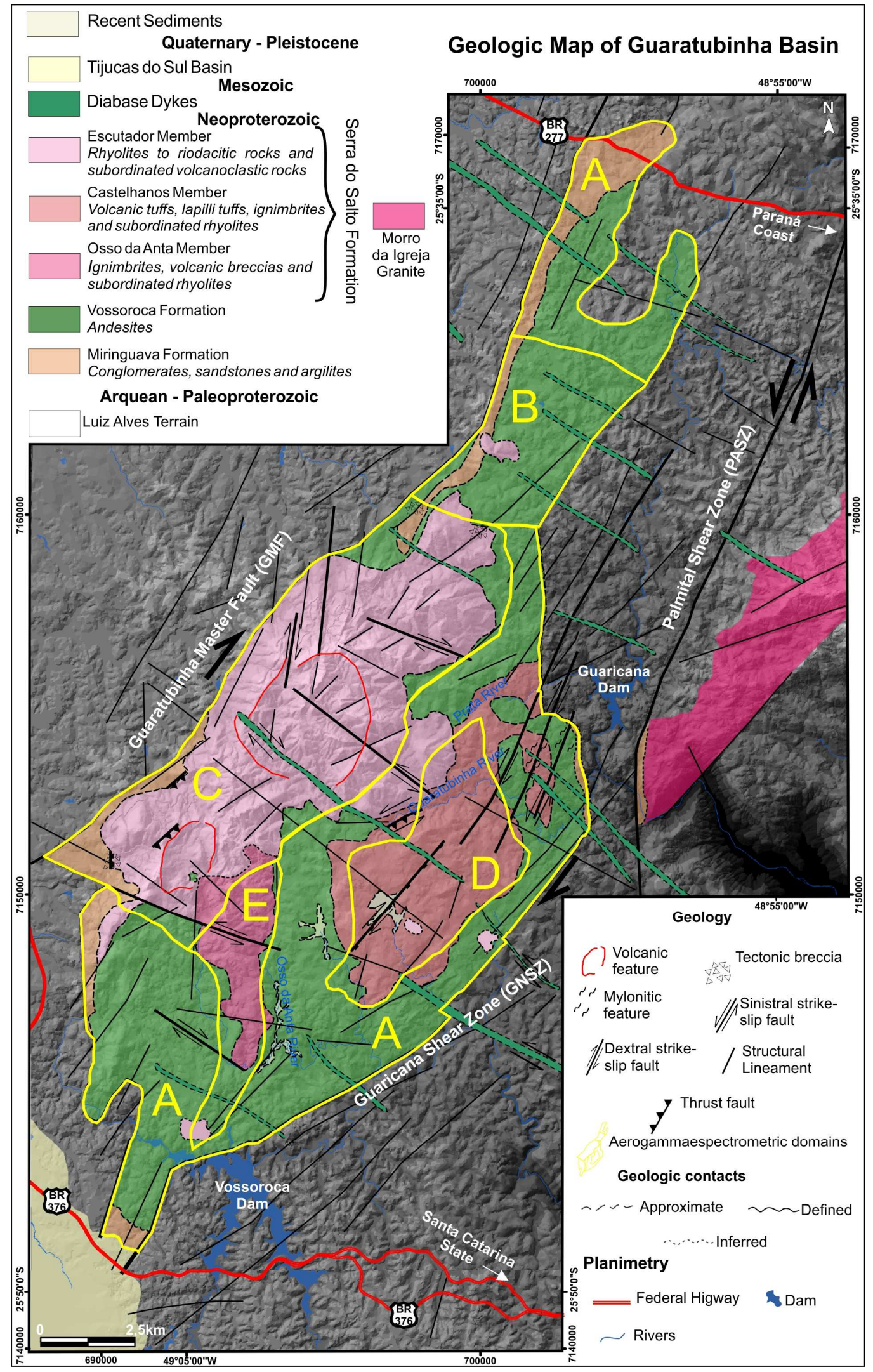

Figure 4 - Geologic map of Guaratubinha Basin correlated to the gamma-ray spectrometric domains. 